\title{
Actual and potential cost effectiveness of off-pump coronary artery bypass grafting in a high-volume cardiothoracic centre
}

\author{
A Page, U Benedetto, E Wlodeck, M Codispoti \\ From 23rd World Congress of the World Society of Cardio-Thoracic Surgeons \\ Split, Croatia. 12-15 September 2013
}

\section{Background}

OPCAB has been shown to be clinically safe and effective, when compared to conventional CABG. However, there is very little data on the cost-effectiveness of OPCAB in unselected patients undergoing myocardial revascularisation in the current era. Therefore, we sought to investigate the impact of OPCAB on perioperative costs in a large cohort of patients undergoing CABG in a high-volume cardiothoracic centre.

\section{Methods}

We analysed the results of 3595 on-pump versus 348 consecutive OPCAB procedures performed by a single surgeon in a high-volume adult cardiothoracic centre by propensity score matching. Hospital costs related to the perioperative care of patients in the two groups were compared, including cost of disposables, blood products, length of stay in theatre, intensive care unit (ICU) and ward areas. Crude and adjusted differences are reported.

\section{Results}

Clinical outcomes were comparable between the two groups. However, OPCAB was associated with a reduced cost per patient in terms of theatre use (crude $-£ 478$ / adjusted $-£ 225)$, ICU (-£ 443 / $-£ 295)$, ward stay ( $£ 66$ /$£ 17)$ and blood products requirement (- $£ 112$ / $-£ 102$ [95\% CI -152 to -53 ]). Overall, the adjusted cost saving per patients was $-£ 1337$ (95\% CI -1938 to -737).

\section{Conclusion}

$O P C A B$ is associated with a significant reduction of hospital costs, when compared to on-pump CABG. If OPCAB

\footnotetext{
* Correspondence: m.codispoti@nhs.net
} Papworth Hospital, Cambridge, UK

(C) 2013 Page et al; licensee BioMed Central Ltd. This is an Open Access article distributed under the terms of the Creative Commons Attribution License (http://creativecommons.org/licenses/by/2.0), which permits unrestricted use, distribution, and reproduction in any medium, provided the original work is properly cited. was adopted by all surgeons performing CABG in a highvolume centre (approximately $1000 \mathrm{CABG}$ procedures/ year), the cost effectiveness of OPCAB could result in savings of $£ 1.5$ million/year.

Published: 11 September 2013

doi:10.1186/1749-8090-8-S1-0194

Cite this article as: Page et al: Actual and potential cost effectiveness of off-pump coronary artery bypass grafting in a high-volume cardiothoracic centre. Journal of Cardiothoracic Surgery 2013 8(Suppl 1): 0194.

Submit your next manuscript to BioMed Central and take full advantage of:

- Convenient online submission

- Thorough peer review

- No space constraints or color figure charges

- Immediate publication on acceptance

- Inclusion in PubMed, CAS, Scopus and Google Scholar

- Research which is freely available for redistribution 